Jurnal Care Vol .5, No2,Tahun 2017

\title{
KETAHANAN PANGAN KELUARGA BERKAITAN DENGAN STATUS GIZI BALITA PASCA ERUPSI GUNUNG BROMO DI KABUPATEN MALANG
}

\author{
Ani Sutriningsih ${ }^{1)}$, Lasri ${ }^{2)}$ \\ ${ }^{1), 2)}$ Program Studi Ilmu Keperawatan Fakultas Ilmu Kesehatan UNITRI \\ email: ani.sutriningsih@gmail.com
}

\begin{abstract}
The eastern part of Malang Regency is a supporting area of agriculture, among others in District Poncokusumo, Pakis, Jabung, and Tumpang. During Mount Bromo issued volcanic ash in December 2015 - February 2016, Tumpang and Poncokusumo areas feel the impact of volcanic ash. This reduces food availability, food access, and food consumption, thus disrupting food security over long periods of time. In emergency situations due to natural disasters of volcanic eruptions and conditions of food security disturbances, the most vulnerable groups have nutritional problems and health problems are under five years old (toddlers). The purpose to determine the relationship of family food security with the nutritional status of toddlers after the eruption of Mount Bromo in Malang regency. This research uses observational design with cross sectional approach. The sample used was 96 families with toddlers. Sampling technique using quota sampling.Instruments using modified questionnaires from the USDA and Kartu Menuju Sehat (KMS). The results indicate that more than half of respondents (76\%) have high family food security and more than half of respondents $(87.5 \%)$ bave good nutritional status. There is a relationship of family food safety with nutritional status of toddlers with correlation coefficient $(r)=1,000$ means have strong relationship strength. Suggestion for respondent family that is to increase family food security through effort of addition of plant variation that more resistant to condition of volcanic ash and addition of livestock type. Posyandu is expected to educate the family about the improvement of nutritional status of toddlers.
\end{abstract}

Keywords: eruption, food security, nutritional status, toddlers

\begin{abstract}
ABSTRAK
Wilayah Kabupaten Malang bagian timur menjadi daerah penopang pertanian, antara lain di Kecamatan Poncokusumo, Kecamatan Pakis, Jabung, dan Tumpang. Selama Gunung Bromo mengeluarkan abu vulkanik pada Desember 2015 - Februari 2016, wilayah Tumpang dan Poncokusumo merasakan dampak abu vulkanik. Hal tersebut menurunkan ketersediaan pangan, akses bahan makanan, dan konsumsi makanan sehingga menganggu ketahanan pangan dalam jangka waktu yang cukup lama. Dalam kondisi darurat akibat bencana alam letusan gunung berapi dan kondisi gangguan ketahanan pangan, kelompok yang paling rentan mengalami masalah gizi dan gangguan kesehatan adalah balita. Tujuan penelitian ini adalah mengetahui hubungan ketahanan pangan keluarga dengan status gizi balita pasca erupsi Gunung Bromo di Kabupaten Malang. Penelitian menggunakan desain observasional dengan pendekatan cross sectional. Sampel yang digunakan sebanyak 96 keluarga yang mempunyai balita. Teknik pengambilan sampel menggunakan quota sampling. Instrumen menggunakan kuesioner modifikasi dari USDA.
\end{abstract}


dan Kartu Menuju Sehat (KMS). Hasil penelitian didapatkan lebih dari separuh responden (76\%) mempunyai ketahanan pangan keluarga kategori tinggi dan lebih dari separuh responden $(87.5 \%)$ mempunyai status gizi balita kategori baik. Hasil uji korelasi Spearman diperoleh $p$ value sebesar $0.049<(\alpha 0,05)$ sehingga ada hubungan ketahanan pangan keluarga dengan status gizi balita dengan koefisien korelasi $(r)=1.000$ artinya mempunyai kekuatan hubungan yang kuat. Saran bagi keluarga responden yaitu meningkatkan ketahanan pangan keluarga melalui upaya penambahan variasi tanaman yang lebih tahan terhadap kondisi abu vulkanik dan penambahan jenis ternak. Bagi posyandu diharapkan memberikan edukasi kepada keluarga tentang peningkatan status gizi balita.

Kata kunci: balita, erupsi, ketahanan pangan, status gizi

\section{PENDAHULUAN}

Indonesia merupakan negara kepulauan yang berada di Jalur Cincin Api Pasifik dimana terdapat 129 gunung berapi atau $21 \%$ dari seluruh gunung berapi yang ada di bumi terletak di Indonesia yang berisiko meletus (BMKG, 2010; Israel, 2010; DeVore, 2010). Letusan gunung berapi menimbulkan kerusakan karena mengeluarkan material berupa lava, abu vulkanik, gas beracun dan menyebabkan hujan asam (Spence et al, 2008; NASA, 2013; Antwi, 2013). Material tersebut dapat merusak tanaman, tanah, hewan, infrastruktur, serta menyebabkan gangguan kesehatan dan perubahan iklim sehingga menurunkan ketersediaan pangan, akses bahan makanan, dan konsumsi makanan sehingga menganggu ketahanan pangan dalam jangka waktu yang cukup lama (Antwi, 2013; WHO, 2013; Becker et al, 2001; Lebon, 2009). Gangguan ketiga komponen ketahanan pangan tersebut (ketersediaan, akses, dan konsumsi bahan makanan) menurunkan asupan makanan yang kemudian akan mempengaruhi status gizi (WFP, 2010).

Pada tanggal 26 November 2010 pukul 17.40 WIB, Gunung Bromo meletus dan mengeluarkan abu vulkanik yang berdampak di 4 kabupaten yaitu Kabupaten Probolinggo, Kabupaten Malang, Kabupaten Pasuruan dan Kabupaten Lumajang. Tanda-tanda erupsi Bromo kembali tampak dalam rentang waktu Desember 2015 - Februari 2016 mengganggu banyak aspek kehidupan. Abu vulkanik Bromo mengganggu kesehatan, sehingga dianjurkan pemakaian masker dan kacamata. Masyarakat yang hidup di sekitar kaldera Tengger, yang sebagai besar petani/peladang, terdampak akibat hujan abu yang menutupi tanaman. Beberapa bandara pun harus 
Jurnal Care Vol .5, No2,Tahun 2017

menghentikan operasinya akibat hujan abu tersebut (http://geomagz. geologi .esdm.go.id, 2016). Terdapat empat wilayah terkena dampak abu vulkanik di Kabupaten Malang antara lain Desa Ngadas di Kecamatan Poncokusumo, Desa Kemiri dan Desa Taji di Kecamatan Jabung, dan Desa Duwet di Kecamatan Tumpang. Penumpukan abu vulkanik yang terus-menerus menyebabkan lapisan atas tanah menjadi resisten terhadap air, sehingga tanaman sulit untuk tumbuh, kecuali tanaman yang berakar panjang. Abu vulkanik ini juga berdampak pada hewan ternak (Lebon, 2009).

Wilayah Kabupaten Malang bagian timur saat ini menjadi daerah penopang pertanian, yang tidak hanya di Kecamatan Poncokusumo saja, namun juga di wilayah Kecamatan Pakis, Jabung, dan Tumpang. Sementara, wilayah Tumpang dan Poncokusumo selama Gunung Bromo mengeluarkan abu vulkanik, kedua daerah ini yang merasakan dampak abu vulkanik. Selain tanaman apel terancam rusak akibat abu vulkanik Gunung Bromo, hal itu juga mengancam produksi tanaman pertanian yang lainnya. Ribuan hektare tanaman sayur berupa kentang, bawang, pare, serta wortel di
Kecamatan Senduro terancam gagal panen jika terkena guyuran abu Bromo (nusa tempo.co.html, 2016), hal ini mempengaruhi ketahanan pangan masyarakat (WFP, 2010) yang mayoritas petani.

Terdapat dua tipe ketidaktahanan pangan dalam rumah tangga yaitu kronis dan transitory. Ketidaktahanan pangan transitory adalah penurunan akses terhadap pangan yang sifatnya sementara, biasanya disebabkan oleh bencana alam yang berakibat pada ketidakstabilan harga pangan, produksi dan pendapatan (Setiawan dalam Kartika 2005). Kelompok yang paling rentan mengalami masalah gizi dan gangguan kesehatan adalah balita (WHO, 2013; The John Hopkins and IFRC Public Health Guide for Emergencies, 2000). Usia dibawah lima tahun (balita) merupakan masa golden age. Masa ini amat penting sekaligus masa kritis dalam proses pertumbuhan dan perkembangan bayi baik fisik maupun kecerdasan. Pada usia 1-2 tahun anak harus memperoleh asupan gizi sesuai dengan kebutuhannya untuk merangsang ukuran maupun fungsi kimiawi dari otak (Depkes, 2004). Keluarga merupakan awal dari kehidupan bagi anak dan anggota keluarga yang lain terutama 
dalam hal pangan, gizi, pendidikan, dan kesehatan yang cukup maka individu tidak akan bisa beraktivitas dengan baik dan produktif secara ekonomi.

Berdasarkan studi pendahuluan yang dilakukan di Posyandu Balita Desa Ngadas di Kecamatan Poncokusumo, Desa Kemiri dan Desa Taji di Kecamatan Jabung, dan Desa Duwet di Kecamatan Tumpang Kabupaten Malang Desa Kemantren Kecamatan Jabung Kabupaten Malang melalui wawancara yang dilakukan terhadap 10 keluarga yang memiliki anak usia balita (1-5) tahun didapatkan bahwa 8 keluarga merasa kesulitan mendapatkan bahan makanan setelah erupsi Gunung Bromo karena banyak lahan pertanian yang rusak dan 6 keluarga menyatakan anaknya yang masih balita mengalami penurunan berat badan karena kekurangan dalam konsumsi makanan dan menderita batuk dan pilek.

\section{METODE PENELITIAN}

Desain penelitian mengunakan desain desain observasional dengan pendekatan cross sectional .Populasi dalam penelitian ini adalah seluruh keluarga yang mempunyai balita di 5 (lima) posyandu yaitu Posyandu Balita Desa Ngadas di
Kecamatan Poncokusumo, Desa Kemiri (Dusun Tengo) dan Desa Taji (Dusun Umbut Legi dan Taji Krajan) di Kecamatan Jabung, dan Desa Duwet di Kecamatan Tumpang Kabupaten Malang. Sampel dalam penelitian ini adalah keluarga yang memiliki anak usia balita dan balita usia 1-5 tahun yang diambil masing-masing sebanyak 30 orang di setiap posyandu, total sampel sebanyak 120 responden dan yang mengisi kuesioner dengan lengkap sebanyak 96 responden yang diambil menggunakan teknik quota sampling. Instrumen dalam penelitian ini menggunakan kuesioner ketahanan pangan keluarga dan Kartus Menuju Sehat(KMS). Kuisioner ini merupakan modifikasi dari kuesioner USDA (2012) untuk mengukur ketahanan pangan keluarga yang berisi pertanyaan tentang pengalaman mengalami kerawanan pangan dalam 1 tahun terakhir. Analisa data menggunakan uji korelasi Spearman Rank dengan bantuan SPSS pada taraf signifikansi $<(\alpha 0,05)$.

\section{HASIL}

\section{Gambaran Umum Lokasi Penelitian}

Penelitian dilaksanakan di Posyandu Desa Ngadas di Kecamatan Poncokusumo, Desa Kemiri dan Desa Taji di Kecamatan Jabung, dan Desa Duwet di Kecamatan 
Tumpang Kabupaten Malang yang terdiri dari 5 (lima) desa yang masuk kriteria inklusi antara lain Posyandu Desa Ngadas (Puskesmas Poncokusumo), Posyandu Desa Kemiri dan Posyandu Desa Taji (Dusun Umbut Legi dan Taji Krajan) (Puskesmas Jabung), dan Posyandu Desa Duwet Krajan (Puskesmas Tumpang). Setiap desa terdapat masing-masing 1 (satu) orang perawat dan bidan yang bertugas di seluruh posyandu di wilayah desa tersebut. Kegiatan posyandu dilaksanakan 1 (satu) kali sesuai dengan tanggal yang sudah ditentukan setiap bulannya dan kegiatan yang dilaksanakan dalam posyandu antara lain pengukuran berat badan dan panjang badan, pemberian makanan tambahan (PMT), imunisasi, pemeriksaan balita sakit, dan pemeriksaan ibu hamil.

Karakteristik berdasarkan usia ayah dan ibu diketahui bahwa $100 \%$ usia ayah 21-50tahun ( rata-rata 31,09tahun) dan $100 \%$ usia ibu 17-45 tahun (rata-rata 25,71 tahun).

Karakteristik berdasarkan pendidikan terakhir ayah diketahui lebih dari separuh (64.4\%) responden ayah mempunyai pendidikan terakhir SD; sebanyak 25\% berpendidikan SMP dan 10,4\% berpendidikan SMA. Sedangkan pendidikan terakhir ibu diketahui lebih dari separuh ibu ( 61,5\%)berpendidikan SD; sebanyak 33,3\% berpendidikan SMP; sebanyak 3,1\% berpendidikan SMA; serta 2,1\% berpendidikan PT.

Karakteristik berdasarkan pekerjaan ayah diketahui lebih dari separuh $(75 \%)$ ayah sebagai petani, sebanyak 14,6\% swasta; sebanyak 4,2\% wiraswatsa dan lain lain 6,3\%. Sedangkan pekerjaan ibu, lebih dari separuh $(64,6 \%)$ sebagai ibu rumah tangga; petani $28,1 \%$; swasta $2,1 \%$ dan lain-lain 5,2\%.

Karakteristik berdasarkan jumlah anggota keluarga diketahui lebih dari separuh (88,5\%) mempunyai anggota keluarga 3-4 orang; dan sebanyak 11,5\% lebih dari 5 orang.

Sebanyak 100\% balita berusia 1-60 bulan, dengan rata-rata 23,72 bulan

Karakteristik responden berdasarkan pendapatan keluarga diketahui sebagian besar keluarga responden (40,6\%) keluarga mempunyai pendapatan $<$ Rp. 500.000,-

Karakteristik responden berdasarkan jenis kelamin diketahui $51 \%$ berjenis kelamin 
perempuan; dan $46,9 \%$ balita berjenis kelamin laki-laki.

Berdasarkan Tabel 1 lebih dari separuh responden $(86.5 \%)$ tidak mempunyai kesulitan dalam persediaan bahan makanan, lebih dari separuh responden (59.4\%) memiliki persepsi bahwa harga bahan makanan pokok (beras) adalah mahal tetapi masih terjangkau, lebih dari separuh responden (59.4\%) tidak pernah mengganti bahan makanan pokok (beras), hampir separuh responden (40.6\%) mempunyai variasi tanaman 1-2 jenis dan lebih dari separuh responden (60.4\%) mempunyai variasi ternak 1-2 jenis yang hasilnya dikonsumsi keluarga dan dijual.

Tabel 1 Identifikasi Ketahanan Pangan Keluarga di Posyandu Desa Ngadas Kecamatan Poncokusumo, Desa Kemiri dan Desa Taji Kecamatan Jabung, dan Desa Duwet Kecamatan Tumpang Kabupaten Malang Tahun 2017

\begin{tabular}{|c|c|c|c|}
\hline \multicolumn{2}{|c|}{ Variabel } & \multirow{2}{*}{$\begin{array}{c}\text { Jumlah } \\
13\end{array}$} & \multirow{2}{*}{$\begin{array}{c}\% \\
13.5\end{array}$} \\
\hline Kesulitan persediaan bahan makanan & 1-6 bulan & & \\
\hline \multirow{4}{*}{ Persepsi harga bahan makanan pokok } & tidak pernah & 83 & 86.5 \\
\hline & murah dan terjangkau & 37 & 38.5 \\
\hline & mahal tapi masih terjangkau & 57 & 59.4 \\
\hline & mahal dan tidak terjangkau & 2 & 2.1 \\
\hline \multirow[t]{2}{*}{ Mengganti bahan makanan pokok } & ya & 39 & 40.6 \\
\hline & tidak & 57 & 59.4 \\
\hline \multirow[t]{3}{*}{ Variasi tanaman } & $1-2$ jenis & 39 & 40.6 \\
\hline & $>3$ jenis & 35 & 36.5 \\
\hline & tidak punya & 22 & 22.9 \\
\hline \multirow[t]{3}{*}{ Variasi ternak } & $1-2$ jenis & 58 & 60.4 \\
\hline & $>3$ jenis & 1 & 1.0 \\
\hline & tidak punya & 37 & 38.5 \\
\hline Total & & 96 & 100 \\
\hline
\end{tabular}

Berdasarkan Tabel 2 pengalaman kerawanan pangan dalam 1 tahun terakhir didapatkan sebagian besar responden tidak pernah mengalami kehabisan bahan makanan atau kehabisan uang untuk membeli bahan makanan (81.3\%), mampu membeli bahan makanan yang lengkap: nasi, sayur, lauk hewani, lauk mengurangi porsi makan makan karena kehabisan bahan makanan (91.7\%), tidak mempunyai frekuensi makan kurang dari 2 bulan dengan durasi $>2$ bulan (92.7\%), tidak mengurangi frekuensi makan karena kehabisan bahan makanan $(92.7 \%)$, dan tetap makan karena kehabisan persediaan makanan (95.8\%). 
Jurnal Care Vol .5, No2,Tahun 2017

Tabel 2 Pengalaman Kerawanan Pangan Keluarga di Posyandu Desa Ngadas Kecamatan Poncokusumo, Desa Kemiri dan Desa Taji Kecamatan Jabung, dan Desa Duwet Kecamatan Tumpang Kabupaten Malang Tahun 2017

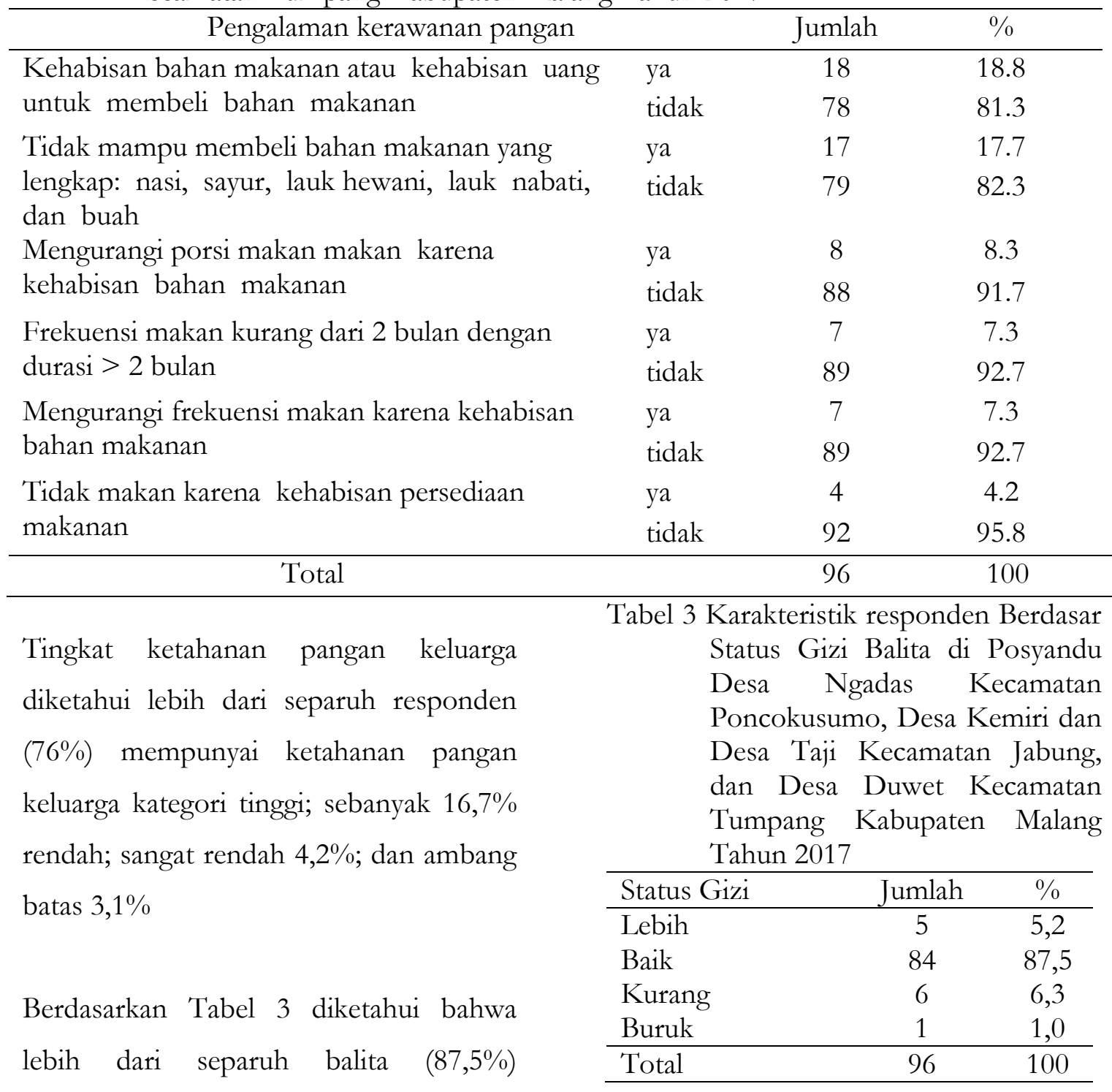

mempunyai status gizi yang baik

Berdasarkan Tabel 4 diketahui keluarga yang memiliki ketahanan pangan tinggi berdampak pada status gizi balita yang $\operatorname{baik}(79,8 \%)$.

\section{Analisa Data}

Analisa data menunjukkan hasil analisis data menggunakan uji korelasi Spearman diperoleh $p$ value sebesar $0.049<(\alpha 0,05)$ sehingga $\mathrm{Ha}$ diterima, artinya ada hubungan antara status gizi balita dengan 
Jurnal Care Vol .5, No2,Tahun 2017

ketahanan pangan keluarga dengan mempunyai kekuatan hubungan yang koefisien korelasi $(\mathrm{r})=1.000$ artinya kuat.

Tabel 4. Tabulasi Silang Ketahanan Pangan Keluarga dengan Status Gizi di Posyandu Desa Ngadas Kecamatan Poncokusumo, Desa Kemiri dan Desa Taji Kecamatan Jabung, dan Desa Duwet Kecamatan Tumpang Kabupaten Malang Tahun 2017

\begin{tabular}{|c|c|c|c|c|c|c|c|c|c|c|c|}
\hline & & \multicolumn{2}{|c|}{ Lebih } & \multicolumn{2}{|c|}{ Baik } & \multicolumn{2}{|c|}{ Kurang } & \multicolumn{2}{|c|}{ Buruk } & \multicolumn{2}{|c|}{ Total } \\
\hline & & $\mathrm{n}$ & $\%$ & $\mathrm{n}$ & $\%$ & $\mathrm{n}$ & $\%$ & $\mathrm{n}$ & $\%$ & $\mathrm{n}$ & $\%$ \\
\hline \multirow{5}{*}{$\begin{array}{c}\text { Ketahanan } \\
\text { Pangan }\end{array}$} & Tinggi & 4 & 80 & 67 & 79.8 & 2 & 33.3 & 0 & 0 & 73 & 76 \\
\hline & Ambang batas/margin & 0 & 0 & 0 & 0 & 3 & 50 & 0 & 0 & 3 & 3.1 \\
\hline & Rendah & 1 & 20 & 13 & 15.5 & 1 & 16.7 & 1 & 100 & 16 & 16.7 \\
\hline & Sangat rendah & 0 & 0 & 4 & 4.8 & 0 & 0 & 0 & 0 & 4 & 4.2 \\
\hline & Total & 5 & 100 & 84 & 100 & 6 & 100 & 1 & 100 & 96 & 100 \\
\hline
\end{tabular}

\section{PEMBAHASAN}

\section{Ketahanan Pangan Keluarga}

Lebih dari separuh responden $(76 \%)$ mempunyai ketahanan pangan keluarga kategori tinggi. Faktor yang mempengaruhi ketahanan pangan antara lain usia, pendapatan, dan jumlah anggota keluarga (Susilowati, 2014).

Faktor pertama yang mempengaruhi ketahanan pangan adalah usia kepala rumah tangga. Dalam penelitian ini rerata usia responden ayah 31.09 tahun yang merupakan usia produktif dalam bekerja. Hal ini didukung bahwa lebih dari separuh $(75 \%)$ responden ayah bekerja sebagai petani dimana seorang petani tersebut mengandalkan tenaga atau fisiknya dalam bekerja, maka semakin produktif usia kepala rumah tangga tinggi. Hal ini didukung oleh penelitian Arene dan Anyaeji (2010) yang menyebutkan bahwa salah satu faktor dominan yang mempengaruhi ketahanan pangan adalah usia.

Faktor kedua yang mempengaruhi ketahanan pangan adalah jumlah anggota keluarga. Beberapa hasil penelitian yang relevan menyebutkan bahwa banyaknya anggota keluarga memiliki pengaruh terhadap jumlah pangan yang dikonsumsi. Dalam penelitian ini sebagian besar responden $(88.5 \%)$ mempunyai jumlah anggota keluarga 3-4 orang (Tabel 1), artinya jumlah anggota yang tidak terlalu banyak menjadi salah satu faktor yang meningkatkan ketahanan pangan keluarga karena jumlah pangan yang dikonsumsi relatif lebih 
sedikit dibandingkan jumlah anggota $>5$ orang.

Faktor ketiga yang mempengaruhi ketahanan pangan adalah pendapatan rumah tangga. Teori Kenyes menyatakan bahwa semakin tinggi pendapatan yang diterima maka semakin tinggi pula konsumsinya sehingga terpenuhinya konsumsi pangan (tahan pangan). Dalam penelitian ini hampir separuh responden $(40.6 \%)$ mempunyai pendapatan $\geq$ Rp. 500.000 - 1.000.000/bulan yang merupakan pendapatan di bawah Upah Minimum Regional Kabupaten Malang Tahun 2017 sebesar Rp. 2.358.610 per bulan. Meskipun pendapatan keluarga masih dibawah UMR hal ini juga didukung dengan adanya sebagian responden yang menanam tanaman dengan variasi 1-2 jenis tanaman (40.6\%) dan memelihara ternak dengan variasi 1-2 jenis ternak (60.4\%). Hasil dari panen tanaman atau ternak yang dipelihara dimanfaatkan untuk konsumsi keluarga dan dijual sehingga sebagian besar responden $(82.3 \%)$ mampu membeli bahan makanan yang lengkap yaitu nasi, sayur, lauk hewani, lauk nabati, dan buah. Beberapa penelitian yang mendukung antara lain penelitian yang dilakukan oleh Halik (2007) dan Arene dan Anyaeji (2010) menyebutkan bahwa salah satu faktor dominan yang mempengaruhi ketahanan pangan adalah pendapatan per kapita. Faktor ini memiliki efek yang positif yang artinya semakin tinggi pendapatan seseorang, maka semakin tinggi pula probabilitas suatu rumah tangga masuk dalam kategori tahan pangan.

Sebagian responden tidak tahan pangan yaitu ketahanan pangan pada ambang batas/margin (3.1\%), rendah $(16.7 \%)$, dan sangat rendah (4.2\%). Faktor yang mempengaruhi ketidaktahanan pangan transitory adalah penurunan akses terhadap pangan yang sifatnya sementara, biasanya disebabkan oleh bencana alam yang berakibat pada ketidakstabilan harga pangan, produksi dan pendapatan (Setiawan dalam Kartika, 2005). Hal ini berkaitan dengan lokasi penelitian yang berada di kawasan yang terdampak abu vulkanik Gunung Bromo pada Desember 2015 - Februari 2016 dan berdampak pada rusaknya hasil tanaman sehingga mengakibatkan gagal panen. Selain itu akses bahan makanan juga dipengaruhi pendapatan dimana hampir separuh responden (38.5\%) mempunyai pendapatan < Rp. 500.000 per bulan dan tidak mempunyai tanaman sebanyak 
$22.9 \%$ dan ternak sebanyak $38.5 \%$. Hal ini didukung oleh penelitian Rahmawati dkk (2014) menunjukkan bahwa dua tahun setelah letusan Gunung Bromo, ketahanan pangan masyarakat di wilayah penelitian masih berada dalam kondisi rawan, keluarga tahan pangan sebanyak $41 \%$, selebihnya ambang batas tahan pangan $(9 \%)$, ketahanan pangan rendah $(43 \%)$ dan ketahanan pangan sangat rendah $(7 \%)$.

\section{Status Gizi Balita}

Lebih dari separuh responden balita (87.5\%) mempunyai status gizi kategori baik. Faktor yang mempengaruhi status gizi balita terdiri dari 2 faktor yaitu faktor internal (nilai cerna makanan, status kesehatan, usia, jenis kelamin, status fisiologi, dan ukuran tubuh) dan faktor eksternal (tingkat pendidikan, tingkat pengetahuan gizi, pendapatan keluarga, jumlah anggota keluarga, latar belakang, sosial budaya, kebersihan lingkungan, dan keadaan infeksi) (Supariasa, 2012).

Faktor internal yang mempengaruhi status gizi balita adalah usia dan status kesehatan. Usia akan mempengaruhi kemampuan atau pengalaman yang dimiliki orang tua dalam pemberian nutrisi pada anak balita (Nursalam, 2001).
Dalam penelitian ini rerata usia responden ayah 31.09 tahun dan rerata usia responden ibu 25.71 tahun (Tabel 1) yang merupakan usia produktif sehingga akan memudahkan dalam menerima informasi berkaitan status gizi balita. Menurut Soetjiningsih (2005) bayi dan anak-anak yang kesehatannya buruk dan adanya status infeksi dan demam adalah sangat rawan karena pada periode hidup ini kebutuhan zat gizi digunakan untuk pertumbuhan cepat. Berdasarkan wawancara dengan responden, ibu menyatakan bahwa balita jarang menderita sakit hanya beberapa yang menderita batuk saat terjadi abu vulkanik.

Faktor eksternal yang mempengaruhi status gizi balita adalah tingkat pendidikan, tingkat pengetahuan gizi, pendapatan keluarga, jumlah anggota keluarga. Pendidikan gizi merupakan suatu proses merubah pengetahuan, sikap, dan perilaku orang tua atau masyarakat untuk mewujudkan status gizi yang baik (Suliha, 2001). Berdasarkan hasil penelitian lebih dari separuh (61.5\%) responden ibu mempunyai pendidikan terakhir SD. Meskipun tingkat pendidikan responden ibu masih tergolong rendah tetapi dengan adanya pengetahuan ibu terhadap gizi dan kesehatan yang baik dan 
Jurnal Care Vol .5, No2,Tahun 2017

jangkauan pelayanan kesehatan (posyandu) yang dekat akan memudahkan akses bagi keluarga untuk mendapatkan informasi tentang peningkatan status gizi balita.

Pendapatan keluarga merupakan salah satu faktor yang mempengaruhi status gizi balita. Dalam penelitian ini hampir separuh responden (40.6\%) mempunyai pendapatan $\geq R$ p.500.000-1.000.000/bulan yang merupakan pendapatan di bawah Upah Minimum Regional Kabupaten Malang Tahun 2017 sebesar Rp. 2.358.610 per bulan. Meskipun pendapatan keluarga masih dibawah UMR hal ini juga didukung dengan adanya sebagian responden yang menanam tanaman dengan variasi 1-2 jenis tanaman $(40.6 \%)$ dan memelihara ternak dengan variasi 1-2 jenis ternak (60.4\%). Hasil dari panen tanaman atau ternak yang dipelihara dimanfaatkan untuk konsumsi keluarga dan dijual sehingga sebagian besar responden (82.3\%) mampu membeli bahan makanan yang lengkap yaitu nasi, sayur, lauk hewani, lauk nabati, dan buah.

Jumlah anggota keluarga juga merupakan salah satu faktor yang mempengaruhi status gizi balita. Beberapa hasil penelitian yang relevan menyebutkan bahwa banyaknya anggota keluarga memiliki pengaruh terhadap jumlah pangan yang dikonsumsi. Nilai gizi makanan juga didapatkan dengan adanya variasi tanaman atau ternak yang dipelihara oleh keluarga sehingga meningkatkan daya beli keluarga terhadap makanan dan lebih dari separuh responden $(88.5 \%)$ mempunyai jumlah anggota keluarga 3 - 4 orang atau jumlah yang cukup untuk mendapatkan makanan untuk balita.

Berdasarkan hasil penelitian sebagian kecil responden balita (6,3\%) masuk kategori status gizi kurang dan sisanya $(1 \%)$ masuk kategori gizi buruk. Keadaan infeksi menurut Supariasa (2012) merupakan salah satu faktor yang mempengaruhi status gizi balita. Terjadinya krisis ekonomi, politik dan sosial termasuk bencana alam, yang mempengaruhi ketidakseimbangan antara asupan makanan dan adanya penyakit infeksi, yang pada akhirnya mempengaruhi status gizi balita (Soekirman, 2000). Hal ini berkaitan dengan lokasi penelitian di daerah yang terdampak abu vulkanik Gunung Bromo pada Desember 2015 - Februari 2016. Berdasarkan hasil wawancara dampak dari abu vulkanik tersebut antara lain 
rusaknya tanaman akibat tertutup abu vulkanik sehingga mengakibatkan petani gagal panen, selain itu abu vulkanik juga berdampak pada beberapa anak dan balita yang mengakibatkan infeksi saluran pernafasan akut (ISPA).

\section{Hubungan Ketahanan Pangan}

\section{Keluarga dengan Status Gizi Balita}

Uji korelasi Spearman diperoleh $p$ value sebesar $0.049<(\alpha 0,05)$ sehingga $\mathrm{Ha}$ diterima, artinya ada hubungan antara ketahanan pangan keluarga dengan status gizi balita dengan koefisien korelasi $(\mathrm{r})=1.000$ artinya mempunyai kekuatan hubungan yang kuat. Menurut UNICEF (1998) ketahanan pangan keluarga merupakan faktor tidak langsung yang mempengaruhi status gizi anak balita. Hal ini sesuai dengan penelitian Rohaedi dkk (2012) yang menyatakan terdapat hubungan yang bermakna antara tingkat ketahanan pangan rumah tangga dengan status gizi balita $(\mathrm{p}<0.0001)$ dan penelitian Natalia (2013) yang menyatakan ada hubungan ketahanan pangan tingkat keluarga dengan status gizi batita $(\mathrm{p}<0.001)$.

\section{KESIMPULAN}

Berdasarkan hasil penelitian dapat diambil kesimpulan antara lain:

1. Lebih dari separuh responden $(87.5 \%)$ mempunyai status gizi kategori baik.

2. Lebih dari separuh responden (76\%) mempunyai ketahanan pangan keluarga kategori tinggi.

3. Ada hubungan antara status gizi balita dengan ketahanan pangan keluarga menggunakan uji Spearman Rank diperoleh $p$ value sebesar 0.049 $<(\alpha 0,05)$ dengan koefisien korelasi $(\mathrm{r})=1.000$ artinya mempunyai kekuatan hubungan yang kuat.

\section{REFERENSI}

Antwi, A. (2013). Climate Change and Food Security: An overview about the issue.

Arene, Anyaeji. 2010. Determinants of Foods Security among Households in Nsukka Metropolis of Enugu State, Nigeria. Pakistan Journal of Social Sciences (PJSS), Vol. 30(1), 916.

Becker J, Smith R, Johnston D, Munro A. (2001). Effects of the 1995-1996 Ruapehu eruptions on communities in central North Island, New Zealand, and 
people's perceptions of volcanic hazards after the event. The Australasian Journal of Disaster and Trauma Studies.

BMKG. (2010).Apakah Gempa bumi itu?,http://inatews.bmkg.go.id/tent ang_eq.php. Diakses 20 Mei 2016.

DeVore V. (2010).Extra feature story, Natural disaster are fact of life in Indonesia's ring of fire, http://newshourtc.pbs.org/newsh our/extra/features/world/julydec1 0/indonesia_11-1. Diakses 20 Mei 2016.

Halik, A. (2007). Ketahanan Pangan Masyarakat Pedesaan (Studi Kasus di Desa Pammusureng, Kecamatan Bonto Cani, kabupaten Bone). Jurnal Agrisistem, Vol. 3(2). http://geomagz.geologi.esdm.go.id Lerupsi-bromo-desember-2015februari-2016/. Diakses 20 Mei 2016.

Israel B.(2010). Indonesia's Explosive Geology Explained.. http://www. livescience.com/8823-indonesia explosive-geology-explained.html. Diakses 20 Mei 2016.

Kartika. (2005). Analisis coping strategy dan ketahanan pangan rumah tangga petani di Desa Majasib Kecamatan Sliyeg Kabupaten Indramayu. (skripsi).
Departemen Gizi Masyarakat dan Sumberdaya Keluarga, Fakultas Pertanian, IPB.

Lebon, S.L.G. (2009).Vulcanic Activity and Environment: Impact on Agriculture and Use of Geological Data to Improve Recovery Process. University of Iceland Faculty of Earth Science.

NASA. (2013). How Do Volcanic Eruptions Affect Society?, http://solidearth.jpl.nasa.gov/PAG ES/volc03.html. Diakses 20 Mei 2016.

Natalia, L.D.(2013). Hubungan Ketahanan Pangan Tingkat Keluarga dan Tingkat Kecukupan Zat Gizi dengan Status Gizi Batita di Desa Gondangwinangun Tabun 2012. Universitas Diponegoro Semarang. Tidak dipublikasikan.

Rahmawati, dkk. (2014). Ketahan Pangan Keluarga Balita Pasca Erupsi Gunung Bromo, Kabupaten Probolinggo, Indonesia. Indonesian Journal of Human Nutrition. Volume 1, Edisi 1, 35-49.

Rohaedi, S., Julia, M., dan Gunawan, I.M.A. (2012). Hubungan antara Tingkat Ketahanan Pangan Rumah Tangga dengan Status Gizi Balita pada Rumah Tangga di Daerah 
Rawan Pangan Kabupaten

Indramayu. Jurnal Giæi dan Dietetik

Indonesia. Vol. 2(2).

Soekirman. (2000). Ilmu Gizi dan Aplikasinya. Departemen

Pendidikan Nasional. Jakarta.

Soetjiningsih. (2005). Tumbuh Kembang Anak. Erlangga. Surabaya.

Spence R, Gunesekara R. (2008). Insurance Risks From Volcanic Eruptions In Europe. London: Willis Research, http://www. willisresearch network.com/assets/templates/wr n/files/WRN $\% 20 \% 20$ Insurance $\%$ 20Risks $\% 20$ from $\% 20$ Volcanic $\% 20$ Eruptions Final.pdf. Diakses 20 Mei 2016.

Supariasa.(2012). Penilaian Status Giri. EGC. Jakarta.

Susilowati, H. (2014). Faktor-faktor yang mempengarubi Ketahanan Pangan Rumah Tangga Miskin di Kecamatan Srandakan Bantul. Universitas Negeri Yogyakarta. Tidak dipublikasikan.

The Johns Hopkins and IFRC Public Health Guide for Emergencies. (2000). Chapter 6. Food and Nutrition, http://www.adpc. net/ upload...ifrc/food/and/nutrition.

Diakses 20 Mei 2016.
USDA.(2012). US Household food security survey module: Three-stage design, with screeners. Economic research service.

WFP. (2010). Nutrition Security and Food Security in Seven Districts in NTT Province, Indonesia: Status, Causes and Recommendations. http://www.un.or.id/documents_u pload/publication//Nutrition $\% 20$ Security $\% 20$ and $\% 20$ Food $\% 20$ Secu rity $\% 20$ in $\% 20$ Seven $\% 20$ Districts $\%$ 20in $\% 20$ NTT $\% 20$ Province $\% 20$ Ind onesia\%202010.pdf., . Diakses 20 Mei 2016.

WHO. (2013). Volcanic Eruptions Natural Disaster Profile - Technical Hazard Sheet, http://www. who.int /hac/techguidance/ems/volcanos/ en/. Diakses 20 Mei 2016 